\begin{tabular}{|c|}
\hline Studia Theologica Varsaviensia \\
UKSW \\
$1 / 2016$ \\
\hline
\end{tabular}

Ks. TADEUSZ ZADYKOWICZ

\title{
WSTYD DOBRY I ZŁY - Z PERSPEKTYWY TEOLOGICZNOMORALNEJ
}

Tematyce wstydu poświęcono ostatnio w literaturze teologicznomoralnej sporo miejsca ${ }^{1}$. Wydaje się, że swoistym impulsem dla zainteresowań etyków chrześcijańskich tym uczuciem była jego analiza zawarta w książce K. Wojtyły Miłość i odpowiedzialność ${ }^{2}$ oraz w papieskich katechezach Mężczyzną i niewiastą stworzyt ich ${ }^{3}$. Drugą przyczynę tego zainteresowania stanowi z pewnością - coraz bardziej powszechne w dzisiejszym świecie - zjawisko bezwstydu ${ }^{4}$. Traktując

${ }^{1}$ Por. W. Pó $ł \mathrm{t}$ a w s k a, Wstyd i wstydliwość jako afirmacja tajemnicy, w:. T. S t y c z en (red.), Jan Pawet II. Mężczyzna i niewiasta stworzyt ich. Chrystus odwotuje się do 'poczatku', Lublin 1981, s. 203-215; I. M r o c z k ow s k i, Osoba i cielesność. Moralne aspekty teologii ciała, Płock 1994, s. 223-224; J. K 1 u s a k, Wokót zjawiska wstydu i wstydliwości, „Seminare”, 12(1996), s. 39-58; A. S a r$\mathrm{m}$ i e n t o, Malżeństwo chrześcijańskie. Podręcznik teologii maleństwa i rodziny, Kraków 2002, s. 78-79; M. G r a b o w s k i, Wstyd i nagość, Toruń 2003; J. K u p c z a k, Dar i komunia. Teologia ciała w ujęciu Jana Pawła II, Kraków 2006; M. P o k r y w k a, Rola wstydu w obronie godności osoby ludzkiej, RT 55(2008), z. 3, 139-152; J. D r w a 1, Moralne aspekty wstydu. Studium teologicznomoralne wświetle posoborowej literatury teologicznej, Lublin 2009.

2 Lublin 1960, 2001, s. 156-172.

3 Chodzi tu zwłaszcza o katechezy wygłoszone między 12. grudnia 1979 roku a 13. lutego 1980 roku.

${ }^{4}$ Por. U. G r e i n e r, Schamverlust: vom Wandel der Gefühlskultur, Reinbek bei Hamburg 2014, s. 33; J. N a g ó r n y, Nudyzm, w: K. J e ż y n a, J. G o c k o, W. R z e p a (red.), Ks. Janusz Nagórny. Ptciowość - miłość - rodzina, Lublin 
je w kategoriach znaku czasu, teologowie moraliści, zajmujący się zwłaszcza etyką seksualną i małżeńsko-rodzinną, koncentrują się na pozytywnych aspektach wstydu i jego roli w życiu moralnym mężczyzn i kobiet, małżonków i rodziców. Podkreślają przy tym wzniosłość tego uczucia oraz jego przydatność w obronie godności osoby ludzkiej. Uczucie wstydu ostrzega bowiem, że dzieje się coś złego i pozwala ocenić, czy człowiek postępuje moralnie, w zgodzie z systemem wartości. W teologii moralnej traktuje się więc wstyd jako właściwe środowisko wzrastania w cnocie, a nawet jako sprawdzian cnotliwości; jako impuls do pracy nad sobą, do przemiany; jako swego rodzaju zabezpieczenie przed niemoralnym, antyspołecznym zachowaniem.

Powstaje jednak pytanie: czy może istnieć także wstyd zły? Nie chodzi tu oczywiście o zanegowanie potrzeby wstydu jako takiego, w myśl poglądów, że ,ludzie wstydliwi są naprawdę godni pożałowania" (Georges Courteline), a wstyd posiada wyłącznie wpływ destrukcyjny i dlatego należy z nim walczyć (psychoanaliza). Poglądy takie pozostają zresztą w zdecydowanej mniejszości. Nawet poza chrześcijaństwem przeważa pozytywna ocena wstydu posunięta aż do swoistej jego apoteozy w duchu stwierdzenia K. Darwina: „Wstydliwość to najbardziej charakterystyczna i najbardziej ludzka z ludzkich cech". Psychologia i pedagogika podkreśla jednak, że nie każdy wstyd buduje; istnieje także wstyd, który niszczy. Warto na ten problem spojrzeć z perspektywy teologicznomoralnej. Aby jednak ocenić wstyd, a zwłaszcza by wskazać jego złe, ,grzeszne” formy, trzeba najpierw dokonać choćby ogólnej charakterystyki tego uczucia.

\section{OGÓLNA CHARAKTERYSTYKA WSTYDU}

Wstyd jest uczuciem powszechnym. Niemal wszyscy czegoś się wstydzą. Każdy człowiek posiada naturalną i spontaniczną potrzebę ukrycia pewnych treści czy wartości w swoim wnętrzu. Każdy

2009, s. 152; Tenże, Nudyzm i naturyzm z perspektywy chrześcijańskiego orędzia moralnego, tamże s. 159. 
odczuwa lęk wobec drugiego człowieka, choć jest to zasadniczo lęk o własne ,ja”’ Ten lęk pojawia się w obliczu zagrożenia jakiejś wartości. Nie ma jednak jednego wstydu. Słowo wyrażające to uczucie jest używane $\mathrm{w}$ wielu różnych sytuacjach i kontekstach. Co więcej, wstyd bywa utożsamiany z uczuciami pokrewnymi, np. z nieśmiałością, strachem, wycofaniem ze społeczności, zaskoczeniem, upokorzeniem, zakłopotaniem, przygnębieniem, żalem. Wiąże się też z takimi postawami, jak skromność, pokora, umiarkowanie. Choć - jak twierdzi św. Tomasz - sam wstyd nie jest cnotą, to stanowi on konieczny warunek i składnik wielu cnót. Jest on np. elementem cnoty czystości. Znajduje on także różne środki wyrazu, zarówno werbalne jak i pozawerbalne; może np. objawiać się ucieczką przed wzrokiem, przed obecnością innych ludzi.

Wstyd może dotyczyć tego, co człowiek zrobił i tego, kim jest. Jednym z jego rodzajów jest wstyd seksualny. Jego istota polega na ukryciu wartości seksualnych o tyle, o ile mogą one stanowić przedmiot użycia przez inną osobę. Przejawia się on w unikaniu takiego eksponowania ciała, które mogłoby wywołać reakcję nieopowiadającą wartości osoby. Zewnętrzne przejawy wstydu seksualnego wiążą się z ciałem, z tymi organami i częściami ciała, które stanowią o jego seksualnej odrębności. W pewien sposób tłumaczy on np. potrzebę unikania nagości ciała. Nie można jednak sprowadzić go tylko do stosowania odpowiedniego stroju. Tym bardziej nie można go utożsamiać z tabu seksualnym. Taka interpretacja, pozostająca jedynie na poziomie zasłaniania ciała, nie oddaje pełnej prawdy o wstydzie.

Wstyd może też mieć różne źródła. W sferze seksualnej może on ujawniać trudność utożsamiania się z własnym ciałem. Może wynikać $\mathrm{z}$ traktowania tej sfery jako z natury złej. Wstyd może być również wynikiem lęku przed zranieniem, wyśmianiem, wykorzystaniem. Jego źródłem bywa niewiedza, obawa w kontakcie z drugą osobą i przed jej oceną. Wstyd rodzi się zwykle w stanach, na które człowiek ma wpływ. Niekiedy jednak dotyczy także sytuacji, które zaistniały

5 Por. J a n P aw e $\nmid$ II, Kat. Personalistyczna petnia pierwotnej niewinności (19.12.1979), nr 1. 
bez jego winy (np. niepełnosprawność, kalectwo, pochodzenie, porzucenie przez współmałżonka) lub rzeczy błahych (np. popełnionej gafy) czy zwykłego zbiegu okoliczności. Człowiek odczuwa wstyd, że jest biedniejszy, mniej wykształcony, gorzej ubrany; że nie potrafi dorównać swoim rywalom. Specyficzną formą wstydu jest wstyd za innych, którego typowym przykładem jest wstyd dzieci alkoholików czy rozwiedzionych rodziców.

W odróżnieniu od poczucia winy wstyd ujawnia się zawsze w konfrontacji z otoczeniem, w kontakcie ze światem zewnętrznym ${ }^{6}$. O ile poczucie winy rodzi się w odniesieniu postępowania do normy wewnętrznej, to wstyd jest wynikiem poczucia nieakceptowalności zachowania przez otoczenie. Poczucie wstydu powstaje na podstawie informacji z zewnątrz, poczucie winy zaś możliwe jest wówczas, gdy człowiek dokona uwewnętrznienia tych informacji i uczyni z nich normę własnego postępowania. Wstyd uświadamia więc istnienie norm społecznych. Nawet jeśli doświadcza się go w samotności, to na wspomnienie lub wyobrażenie siebie w oczach innych. Jest on zatem reakcją na ryzyko bycia wyłączonym ze wspólnoty, na niebezpieczeństwo odrzucenia, na obawę krytyki lub nieprzychylnej opinii ze strony innych 7 . Nic więc dziwnego, że jego intensywność zależy w znacznym stopniu od tradycji kulturowej, która danego człowieka ukształtowała.

Słowo wstyd zawiera w sobie pewne paradoksy. Można wstydzić się dobra, a nie wstydzić się zła. Także Pismo Święte raz wskazuje na pozytywne aspekty, wręcz na obowiązek wstydu, a kiedy indziej zwłaszcza w zapowiedziach mesjańskich - anonsuje jego przemijalność: ,wstydu nie zaznasz” (Iz 54, 4), a nawet przypisuje go głupcom: „wstyd jest udziałem głupców” (Prz 3, 35). Dlatego z moralnego punktu widzenia istotne jest określenie powodów wstydu. Tak samo

${ }^{6}$ Biblijnym obrazem takiego „wstydu wobec ludzi” jest opisane w Księdze Syracha odstąpienie od obyczajowości swojego środowiska a uleganie wpływom obcym (w czasach Syracha były to wspływy helleńskie) (por. 41, 19).

7 Por. M.-S. L o t te r, Scham, Schuld, Verantwortung: über die kulturellen Grundlagen der Moral, Berlin 2012, s. 89. 
bowiem wstydzi się dziecko, które otrzymało mniej wartościowy prezent niż inni i przestępca, który strzelił, ale nie trafił ${ }^{8}$. Istnieje wstyd prawdziwy i fałszywy, konfesyjny i libertyński. Istnieje nawet wstyd zbawczy ${ }^{9}$. Każdy z nich jest oznaką jakiejś wrażliwości, która coś wyklucza, coś blokuje. Za prawdziwe należy więc uznać stwierdzenie: powiedz, czego się wstydzisz, a powiem ci, kim jesteś, w jakim świecie żyjesz; w świecie jakich nakazów i wartości.

\section{MORALNA OCENA WSTYDU}

Wstyd jest związany tylko z osobą i z jej wnętrzem. Wstydzić się może tylko człowiek. Jako osobowe przeżycie jest on także doświadczeniem wobec osoby: Boga, drugiego człowieka i wobec siebie ${ }^{10}$. Jego pozytywna rola w życiu moralnym polega na wskazywaniu zagrożeń wartości oraz ich wewnętrznym zabezpieczaniu ${ }^{11}$. Obawa przed wykorzystaniem, odrzuceniem bądź niewłaściwym zinterpretowaniem wartości powoduje chęć ukrycia tego, co jest dla człowieka najistotniejsze. Wstyd wiąże się więc z lękiem o własne ,ja” wobec drugiej osoby i wyraża potrzebę akceptacji oraz afirmacji tegoż ,ja". Taki lęk, jako reakcja na zło dostrzeżone, wyobrażone lub uświadomione, jest sprzeciwem człowieka wobec prób sprowadzania go do roli przedmiotu używania, sposobem zachowania godności ciała. Jego szczególną rolą jest wskazywanie na zagrożenia wartości osoby i zabezpieczenie tej wartości, a także ochrona osobowej wartości ciała i ludzkiej seksualności' ${ }^{12}$.

Wstyd wiąże się zarówno z chęcią ukrycia zła, jak i dobra, wartości, nadzwyczajnych przeżyć, które zdaniem sprawcy winny pozostać

\footnotetext{
${ }^{8}$ O wstydzie przyłapanego na swoim postępku złodzieja mówi już Stary Testament (por. Jr 2, 26).

9 Por. J a n P a w e 1 II, Homilia podczas Mszy św. beatyfikacyjnej Karoliny Kózkówny (Tarnów, 10.06.1987), nr 3.

${ }^{10}$ Por. J a n P a w eł II, Kat. Ciało nie poddane duchowi rozbija jedność człowieka jako osoby (28.05.1980), nr 1-2.

${ }^{11}$ Por. tamże, nr 6.

12 Por. M. Pok r y w k a, Rola wstydu w..., art. cyt., 147.
} 
w ukryciu ${ }^{13}$. Posiada on sens moralny przez to, że chroni ludzką godność, autentyczną miłość, intymność. Łącząc się z doświadczeniem i przekonaniem osoby o własnej wartości, stoi on na straży tej wartości oraz tego, co składa się na tę wartość. Wstyd spełnia więc funkcję ochronną, ponieważ ostrzega przed naruszeniem wartości osoby, przed jej użyciem i wykorzystaniem bez należnego jej szacunku. Wyraża on wewnętrzną potrzebę unikania takich reakcji na ciało, które pozostają w kolizji z wartością osoby. Dlatego otwiera on człowieka na prawdziwą miłość, w której wartości seksualne zostają podporządkowane dobru całej osoby. Pełni on tym samym podwójną rolę: ochrania i objawia wartość osoby, jako że spontaniczna potrzeba ukrycia samych wartości (np. seksualnych) związanych z osobą jest naturalną drogą do odsłonięcia wartości samej osoby ${ }^{14}$.

Ponieważ wstyd odzwierciedla hierarchię wartości człowieka, jego etos, pojawia się on wtedy, gdy to, co w tej hierarchii posiada niższą wartość zostaje postawiane wyżej. Przez to pomaga on w odkryciu obiektywnych wartości, które odpowiadają prawdziwemu dobru osoby i jest pamięcią o realizacji zadanej przez Boga pełni człowieczeństwa. Jako reakcja na poznane zło, wstyd stoi na straży moralności, jest konieczny do poprawy z wad i rozwoju cnót; stanowi siłę moralną osoby. Niekiedy wręcz prowokuje on postawy pozytywne, np. odczucie wstydu, że kogoś się obraziło, może prowadzić do pojednania, przeproszenia.

W ocenie moralnej wstydu trzeba wziąć pod uwagę, że rodzi się on zawsze z niedostosowania do norm i zasad obowiązujących w społeczności. Dlatego chroni on przed podejmowaniem działań uznanych przez społeczność za niemoralne. Umożliwia ocenę swoich czynów w świetle „obowiązującej” moralności. Niezależnie od tego, czego dotyczy, zawsze rodzi pewien dyskomfort, a niekiedy jest ambiwalentny lub wprost zły pod względem moralnym. Już nawet pobieżny opis samego zjawiska wstydu pokazuje, że nie każdy jest dobry i nie każdy jest uzasadniony. Ambiwalencję oceny moralnej

\footnotetext{
${ }^{13}$ Por. T. Z a d y k o w i c z, Wstyd, w: EK t. 20, kol. 1010.

14 Por. tamże, kol. 1010-1011.
} 
tego uczucia widać nawet w języku potocznym, który zawiera zarówno wezwanie do porzucenia tej postawy („nie wstydź się”, „nie ma się czego wstydzić”), jak i nacechowane surowością „,wstydź się", czy nawet wyrzutem „wstydu nie masz”. Także Pismo Święte mówi o takim wstydzie, który przysparza sławy i wdzięku i takim, który przywodzi do grzechu (por. Syr 4, 21). Mędrzec opisuje szereg sytuacji, w których wstydliwość jest wymagana, ale też przypadki, kiedy kierowanie się wstydem jest dowodem braku roztropności lub słabości.

Dobrym jest wstyd, za którym kryje się wrażliwość moralna. Wstydzić się więc należy przede wszystkim grzechu, który nie tylko obraża Boga, ale także ludzi, przeciwko którym jest skierowany (por. Syr 41, 17-18). Pozytywnie należy ocenić także uczucie wstydu, które powstrzymuje od działań złych. Podobnie przedmiotem wstydu winno być wszystko, co jest wyrazem słabości charakteru i co jest sprzeczne z zasadami dobrego wychowania (por. Syr 41, 19-27). Wstyd tego rodzaju jest zawsze wskazany i budzi życzliwość u ludzi. Jako zdrowe uczucie jest normalną ludzką emocją, która informuje człowieka o jego ograniczeniach, sygnalizuje pewne granice, w ramach których może on czuć się bezpiecznie. Gdy granice te zostaną przekroczone, zdrowy wstyd dostarcza energii do działania. Natomiast zanik wszelkiego uczucia wstydu jest oznaką wielkiej rozwiązłości (por. Am 2, 7). Konstruktywny jest także wstyd wywołany stanem, na który człowiek ma wpływ (np. otyłość, która nie jest wynikiem choroby). Wstyd odczuwany w takim stanie może stanowić mobilizację do pracy nad sobą i nad swoim wyglądem zewnętrznym.

Wstyd jako pozytywne uczucie spełnia funkcję wychowawczą, daje możliwość doskonalenia moralnego. Wzmacnia on poczucie wartości, godność osoby, która go doświadcza, uczy poszanowania własnego ciała, broni integralności człowieka, zapewnia prawidłowy kierunek jego rozwoju, wysubtelnia wrażliwość moralną. Szczególną rolę odgrywa on w wychowaniu do czystej miłości. Pozwala bowiem zharmonizować życie emocjonalno-uczuciowe z całą osobą.

Ambiwalencja wstydu lub nawet jego zło zaczyna się wówczas, gdy człowiek wstydzi się czegoś, co jest dobre, cenne i ważne; co 
należy do jego istoty; co jest nim samym lub istotną jego częścią. Człowiek owładnięty złym wstydem (w psychologii nazwanym niekiedy toksycznym ${ }^{15}$ ) jest w nieustającym konflikcie z samym sobą. Taki wstyd objawia się jako poczucie własnej niedoskonałości, ułomności. Nie tyle sygnalizuje on ograniczenia, ile narzuca poczucie bezwartościowości. Utożsamia się on właściwie z lękiem przed innymi i lękiem przed samym sobą. Przedmiotem tego lęku jest uzewnętrznienie siebie, własnego ,ja". Taki wstyd zniewala, prowadzi do braku zaufania, a nawet do pogardy względem siebie.

Wstyd jest zły, gdy jego przedmiotem są rzeczy dobre. Swoisty katalog rzeczy, których nie należy się wstydzić podaje Księga Syracha: „Nie wstydź się następujących rzeczy i nie grzesz przez wzgląd na osobę: Prawa Najwyższego i Przymierza, i wyroku, który usprawiedliwia nawet bezbożnych, rozliczenia z towarzyszem i podróżnymi i [podziału] darów dziedzictwa bliskich, dokładności wagi i ciężarków i zarobku wielkiego lub małego, korzyści przy sprzedażach kupieckich, częstego karcenia dzieci, skrwawienia boków słudze niegodziwemu" (42, 1-5). Złym zatem byłby wstyd, którego przedmiotem byłoby wykonywanie przepisów Prawa czy kierowanie się zasadami sprawiedliwości. Szczytem takiego złego wstydu jest wstyd wobec Jezusa i Jego słów (por. Mk 8, 38). Współcześnie taki wstyd odwodzi chociażby od pielęgnowania czystości ${ }^{16}$.

Wstyd jest dobry wtedy, gdy rodzi się w obliczu przekroczenia norm moralnych, np. krzywdy wyrządzonej drugiemu człowiekowi. Jeżeli wyraża on świadomość obiektywnie złego postępowania i żal z powodu, że takie działanie się podjęło, to jest to wstyd jak najbardziej konstruktywny. Taki wstyd bowiem, związany z poczuciem winy, może stanowić inspirację do naprawy sytuacji. Gdy natomiast dotyczy zwyczajowych sposobów postępowania, konwenansów, podlega ocenie o tyle, o ile te konwenanse pozostają w relacji do norm.

\footnotetext{
15 Por. J. B r a d s h a w, Toksyczny wstyd. Jak uzdrowić wstyd, który cię zniewala?, Warszawa 1997.

16 Por. J a n P a w eł II, Homilia podczas kanonizacji bł. Kingi (Stary Sącz, 16.06.1999), nr 5.
} 
W poczuciu wstydu można mówić także o pewnej przesadzie. Wstydu może być za dużo. Człowiek może odczuwać wstyd, mimo że nie ma ku temu powodów. Tymczasem tylko wstyd w dobrej dawce może powstrzymywać człowieka przed podejmowaniem złych działań. Gdy jest go za dużo, traci on swoją funkcję realnej oceny dobra i zła. Odczuwany „za bardzo” może paraliżować działanie człowieka. Może okazać się uczuciem, które utrudnia relacje społeczne, nawiązywanie zwłaszcza nowych kontaktów, wyrażanie swoich poglądów. Tworzenie relacji, odnajdywanie się w nowych sytuacjach utrudnia zwłaszcza wstyd utożsamiony ze zwyczajną nieśmiałością. Hamując zdolność komunikowania siebie, jest uczuciem społecznie destrukcyjnym. Wprawdzie do istoty wstydu należy to, że chroni on przed niebezpieczeństwem, taka jest jego rola, ale przecież niebezpieczeństwo może być pozorne. Podobnie, do istoty wstydu należy to, że oddala on jedną osobę od drugiej, ale zarazem szuka osobowego zbliżenia ${ }^{17}$. Człowiek tymczasem może zatrzymać się na tym poczuciu niebezpieczeństwa i oddaleniu, tłumacząc wstydem swój dystans do drugiego człowieka i do wspólnoty.

W ocenie moralnej wstydu trzeba więc wziąć pod uwagę jego konsekwencje społeczne. Wstyd zwykle prowadzi do zamykania się, unikania innych. Źle pojęty może być motywem odejścia od człowieka, jak to miało miejsce w przypadku otoczenia Pawła (por. 2 Tm 1, 15-16). Tymczasem konstruktywnym byłby dopiero taki wstyd, który prowadzi w stronę drugiego człowieka i który byłby w stanie przywrócić człowieka społeczności. Przykładem takiej postawy braku fałszywego wstydu jest postawa Jezusa, który „nie wstydzi się” nazywać ludzi swoimi braćmi (por. Hbr 2, 11; por. także: Hbr 11, 16).

Ocenie moralnej podlega także tzw. wstyd za innych. Może być on wyrazem odpowiedzialności za innych i za całe życie społeczne, w którym obiektywne normy nie są akceptowane (por. 1Kor 5, 2). Gdy jednak człowiek bardziej wstydzi się za innych niż za siebie, może to być oznaką faryzeizmu. Poza tym wstyd za innych nie może

17 Por. Ja n P a w e $\nmid$ II, Kat. Personalistyczna petnia pierwotnej niewinności (19.12.1979), nr 1. 
też eliminować roztropności ani paraliżować odwagi tam, gdzie zapobiegłaby ona powstaniu jakiejś szkody. Fałszywy wstyd byłby w takim przypadku zwykłą oznaką małoduszności.

Człowiek może wstydzić się „,konserwatywnych” poglądów, które choć nie akceptowane przez społeczeństwo, odpowiadają godności człowieka. Może wstydzić się rzeczy błahych (np. wyglądu zewnętrznego, statusu społecznego i materialnego, niemodnych ubrań lub zwykłych gaf), a także cech, na które nie ma wpływu (np. ubóstwo). Taki wstyd utożsamia się właściwie z obniżonym poczuciem wartości i z przeświadczeniem, że ocena wystawiana jest nie na podstawie zachowań, ale statusu materialnego czy wyglądu. Wstyd spowodowany poczuciem, że się nie dorównuje ideałowi propagowanemu przez media (wygląd, sprawność fizyczna), może świadczyć o zachwianej hierarchii wartości. Złym byłby też taki wstyd, który opierałby się wyłącznie na ocenie zewnętrznej, społecznej, a nie wynikałby z obiektywnego systemu wartości.

To wszystko pokazuje, że także sama postawa wstydu winna być formowana, ponieważ możliwe są liczne formy wstydu fałszywego, pruderii. Zresztą to nie wstyd jest celem wychowania; on jest raczej narzędziem. Celem jest zdrowe poczucie winy i świadomość grzechu, którego wstyd jest tylko jednym z elementów. Konieczność wychowania wstydu wynika również ze współczesnych uwarunkowań, które prowadzą do deprecjonowania jego wartości, ośmieszania, co dzisiaj przyjęło postać bezwstydu czyli obnażania z intymności, ekshibicjonizmu, sposobu bycia lub postępowania, w którym wartości seksualne zostają postawione przed wartością osoby. W tym kontekście konieczne jest formowanie postawy zwanej wstydliwością, która wyraża stałą gotowość do unikania tego, co bezwstydne.

$$
* * *
$$

Im postępowanie człowieka jest bardziej godziwe, tym rzadziej musi się on wstydzić. Taki człowiek nawet nie uświadamia swojego wstydu. Z drugiej strony, o tyle ludzie potrafią się zawstydzić, o ile zachowali jeszcze świadomość różnicy między dobrem a złem. Czy 
jednak wstyd zawsze prowadzi do rozwoju życia moralnego? Choć z pewnością nie jest on jedyną drogą do poprawy człowieka i społeczności, to może on być jakimś impulsem do bardziej przyzwoitych zachowań, pod warunkiem że będzie to wstyd dobry. Wstyd bowiem może być dobry i zły, uzasadniony i nieuzasadniony. Może wynikać z miłości, ale i z lęku. Jego przedmiotem mogą być działania nieetyczne, nawet jeśli są one elementem etosu danej społeczności, ale niestety może on także paraliżować człowieka w jego dobrym działaniu. Może budować i może niszczyć. Buduje taki, który wysyłając informację o brakach mobilizuje do działania, reguluje zachowania społeczne. Taki wstyd nakazuje liczyć się z opinią innych, ale też z tej opinii nie czyni ostatecznego źródła moralności. Prawdziwy wstyd domaga się pełnej miłości. Prawdziwy wstyd powinien zostać wchłonięty, zaabsorbowany przez prawdziwą miłość, która afirmując wartość osoby szuka jej najpełniejszego dobra.

Wstyd jest uczuciem i jak każde uczucie winno być poddane rozumowi i woli. Jego przeżywanie jest ważne. Jest on człowiekowi potrzebny, ale niekiedy trzeba nad nim panować, a nawet z nim walczyć. Może on pomóc w przestrzeganiu zasad moralnych. Może dawać cenne wskazówki o tym, co się stało i co należy czynić. Pozwala współżyć z innymi. Brak takiego wstydu może prowadzić do niewłaściwych zachowań. Jednak jego nadmiar może stanowić źródło cierpienia i prowadzić do zahamowania aktywności, wycofywania się z życia i ograniczać człowieka.

\section{Streszczenie}

Tematyka wstydu pojawia się w teologii moralnej zwłaszcza w powiązaniu z refleksją nad życiem małżeńsko-rodzinnym, dla którego - jak się podkreśla istotną formą przygotowania jest właśnie uczucie wstydu, pielęgnowane zwłaszcza na płaszczyźnie życia seksualnego. W opracowaniach teologicznomoralnych raczej rzadko mówi się o wstydzie negatywnie. Tymczasem wstyd, oprócz wszystkich swoich pozytywnych aspektów, może być także zły, osobowo i społecznie destrukcyjny. Może on posiadać niewłaściwy przedmiot i przesadne natężenie. Dlatego 
wstyd, jak każde uczucie, wymaga formacji i poddania go rozumowi i woli, a nade wszystko wprzęgnięcia go w służbę miłości.

\section{Shame - Good and Bad. A Moral Theological Perspective Summary}

The subject of shame appears in moral theology especially in conjunction with a reflection on marital and family life, for which - as it emphasizes - an important form of preparation is nurturing the feeling of shame, especially at the level of sexual life. Studies of moral theology rarely talk about shame negatively. Meanwhile shame, in addition to all its positive aspects, can also be bad; personally and socially destructive. Shame may have the wrong object and an exaggerated intensity. Therefore shame, like every emotion, requires formation and subjecting it to reason and will, and above all harnessing it in the service of love.

Słowa kluczowe: wstyd, moralność, płciowość

Key words: shame, morality, sexuality

Nota 0 autorze: ks. Tadeusz Zadykowicz - doktor habilitowany teologii w zakresie teologii moralnej; profesor nadzwyczajny przy Katedrze Teologii Moralnej Fundamentalnej KUL; dyrektor Instytutu Teologii Moralnej KUL. Główne kierunki badań: wychowanie moralne; wzory osobowe w życiu moralnym; procesy naśladowcze z perspektywy teologicznomoralnej; współczesny kontekst życia religijno-moralnego; biblijne oraz kulturowe przesłanki moralności; moralność pracownika naukowego oraz prowadzenia badań naukowych.

\section{Bibliografia}

Bradshaw J., Toksyczny wstyd. Jak uzdrowić wstyd, który cię zniewala?, Warszawa 1997.

Drwal J., Moralne aspekty wstydu. Studium teologicznomoralne w świetle posoborowej literatury teologicznej, Lublin 2009.

Grabowski M., Wstyd i nagość, Toruń 2003;

Greiner U., Schamverlust: vom Wandel der Gefühlskultur, Reinbek bei Hamburg 2014.

Jan Paweł II, Kat. Personalistyczna pełnia pierwotnej niewinności (19.12.1979). 
Jan Paweł II, Homilia podczas Mszy św. beatyfikacyjnej Karoliny Kózkówny (Tarnów, 10.06.1987).

Jan Paweł II, Kat. Ciało nie poddane duchowi rozbija jedność człowieka jako osoby (28.05.1980).

Jan Paweł II, Homilia podczas kanonizacji bł. Kingi (Stary Sącz, 16.06.1999).

Klusak J., Wokół zjawiska wstydu i wstydliwości, „Seminare” 12(1996), s. 39-58.

Kupczak J., Dar i komunia. Teologia ciała w ujęciu Jana Pawła II, Kraków 2006.

Lotter M.-S., Scham, Schuld, Verantwortung: über die kulturellen Grundlagen der Moral, Berlin 2012.

Mroczkowski I., Osoba i cielesność. Moralne aspekty teologii ciała, Płock 1994.

Nagórny J., Nudyzm i naturyzm z perspektywy chrześcijańskiego orędzia moralnego, w: Ks. Janusz Nagórny. Ptciowość - miłość - rodzina, red. K. Jeżyna, J. Gocko, W. Rzepa, Lublin 2009, s. 155-165.

Nagórny J., Nudyzm, w: Ks. Janusz Nagórny. Ptciowość - miłość - rodzina, red. K. Jeżyna, J. Gocko, W. Rzepa, Lublin 2009, s. 145-153.

Pokrywka M., Rola wstydu w obronie godności osoby ludzkiej, RT 55(2008), z. 3, 139-152.

Półtawska W., Wstyd $i$ wstydliwość jako afirmacja tajemnicy, w: Jan Pawet II. Mężczyzna i niewiasta stworzyt ich. Chrystus odwotuje się do 'początku', red. T. Styczeń, Lublin 1981, s. 203-215.

Sarmiento A., Matżeństwo chrześcijańskie. Podręcznik teologii maleństwa i rodziny, Kraków 2002.

Wojtyła K., Miłość i odpowiedzialność. Lublin 2001.

Zadykowicz T., Wstyd, w: EK t. 20, kol. 1010-1011. 